\title{
ECONOMIC-ENVIRONMENTAL COMPARISON BETWEEN FLAT PLATE AND EVACUATED TUBE SOLAR COLLECTORS
}

\section{HOFFMANN R. BRONDANI M. \\ PAPPIS F. FRIDERICHS A. \\ SERAFINI S. \\ FOLETTO E.L.*}

\author{
Department of Chemical Engineering \\ Federal University of Federal de Santa Maria, Santa Maria, Brazil
}

Received: 06/03/2014

Accepted: $16 / 10 / 2014$

Available online: $20 / 10 / 2014$ *to whom all correspondence should be addressed: e-mail: efoletto@gmail.com

\section{ABSTRACT}

This work employs the environmental methodology of Life Cycle Assessment (LCA) in compliance with ISO 14040 and uses software SimaPro ${ }^{\circledR}$ 7.3.2 to compare the environmental impact in process production of flat plate and evacuated tube solar collectors. In addition, an economic analysis was performed based on the acquisition budgets and the operation of such types of collectors. The results show that the manufacturing of flat plate solar collectors has larger environmental impact, and carcinogen is the major category which causes environmental impact in both types of collector as a result of the consumption and emission of arsenic and cadmium ions. Economically, the cost of acquisition of evacuated tube solar collectors is $104.04 \%$. Therefore, the choice for a specific kind of collector depends on the desired advantages, and a complement is required for decision-making based on the availability of economic resources.

Keywords: solar collectors, evacuated tube, flat plate, economic-environmental analysis, life cycle assessment.

\section{Introduction}

The industrial and population growth has intensified the use of energy resources in order to meet the most diverse needs, to produce wealth and to provide comfort and better quality of life. The current demand for energy is supplied mostly by non-renewable sources such as oil and coal. However, particular characteristics of these sources, such as their finite character and, particularly for oil, price instability, have worried the world community. Furthermore, the atmospheric emission profile of materials such as carbon dioxide and carbon monoxide, sulphur dioxide and particulate materials during their production and use is worrisome, because it emphasizes environmental problems such as global warming and acid rain, among others. In this context, the use of renewable energy from sources such as the sun, winds and biomass poses a promising alternative to the energetic challenges and the mitigation of environmental impacts. In many parts of the world, direct solar radiation is considered one of the most prospective sources of energy (Muthusivagami et al., 2010). The direct use of solar energy is also of a great economic interest and helps mitigate greenhouse effect gases (Michels et al., 2008). Solar energy is emerging as one of the most promising renewable sources because it can be used both to produce thermal energy (heat) by means of solar radiation and to generate mechanical or electric power (photovoltaic effect). However, renewable sources of energy are not exempt from the possibility of 
environmental impacts. They are often presented as "clean sources", not considering the impacts related to industrial production (Ardente et al., 2005). For this reason, their manufacturing process needs to be analyzed because it consumes energy and raw materials that can be associated with environmental pollution.

A wide range of studies have investigated and verified the least environmental impact caused by the use of renewable energy as opposed to the use of non-renewable energy, especially comparing the use of solar collectors and the use of conventional heating systems (natural gas and electric power) (ReyMartínez et al., 2008; Kalogirou, 2009; Hang et al., 2012). Some studies have also economically compared solar collectors with traditional ones (Ozsabuncuoglu, 1995), while others aimed to optimize the performance of solar collector in a general form (Szargut and Stanek, 2007). Among solar collector types, flat plate and evacuated tube collectors are the most frequently investigated ones, but such comparisons address characteristics such as sensitivity, efficiency, loss coefficient or composition and/or configuration (Kalogirou, 2004; Matuska and Sourek, 2006; Kim et al., 2007; Zambolin and Col, 2010), alternatively, only an environmental comparison is made (Ardente et al., 2005; Pehnt, 2006; Kalogirou, 2009). A few works have been reported on the comparison of the types of solar collectors as regards environmental impacts as well as acquisition cost analyses and simultaneous installation. Comparative studies on environmental and economic aggregate aspects among types of solar collectors are necessary in view of the current importance of such information at the time of acquiring solar collectors.

In this context, this study aimed to evaluate the best alternative between two models of solar collectors, flat plate type (Fig. 1) and type evacuated tube (Fig. 2), both economically and environmentally. This system is intended to partially replace the use of fuel oil to heat the swimming pools of Physical Education and Sports Centre (CEFD) at the Federal University of Santa Maria (UFSM), Brazil.

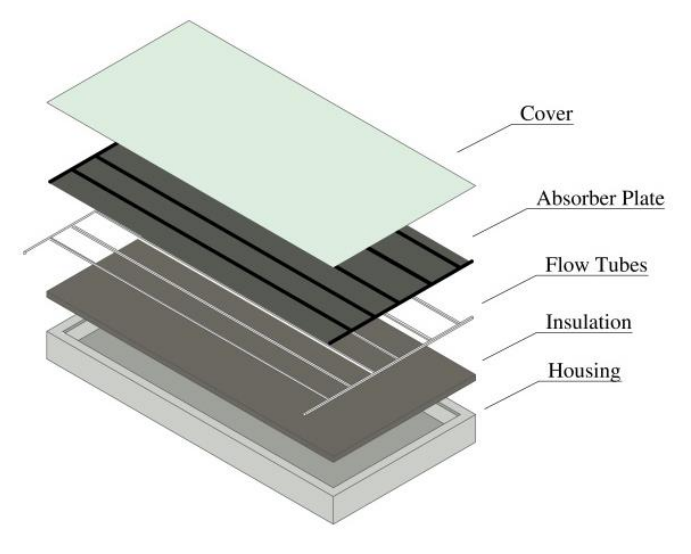

Figure 1. Scheme of solar collector flat plate type

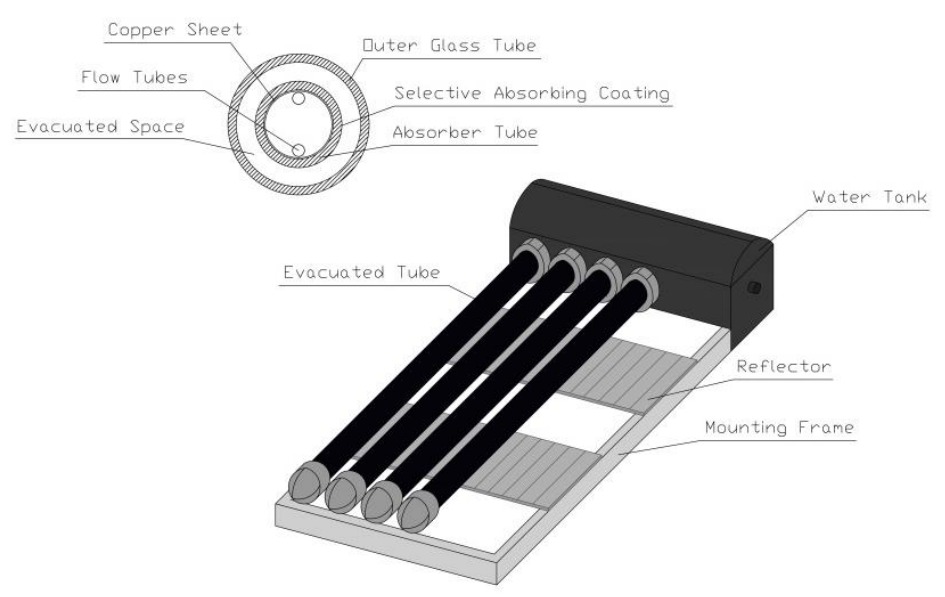

Figure 2. Scheme of solar collector evacuated tube type 
This evaluation is based on an environmental study through Life Cycle Assessment (LCA), whose applicability has been verified in several studies (Tsilingiridis et al., 2004; Battisti and Corrado, 2005; Ma et al., 2010; Cellura et al., 2011; Simons and Firth, 2011; Hang et al., 2012). LCA encompasses the manufacturing process of flat plate and evacuated tube collecting plates as well as an economic feasibility study.Although there are several studies comparing the performance of these collectors, at the best of our knowledge, there are no reports in literature concerning the economic-environmental comparison between flat plate and evacuated tube solar collectors.

\section{Materials and methods}

The amount of each type of collectors was estimated based on the available area and for maximum energy production for each type of solar collector. From the evaluation of the conditions of the installation location for collectors, it was possible to specify the amount of each type of collector that can be installed. Factors as the geometric conformation of each collector type, the quality of the working fluid and the temperature of application also influenced the threshold quantity of collectors. The data used in this study are presented in Table 1.

Table 1. Data of the project

\begin{tabular}{|c|c|}
\hline Information & Details \\
\hline Installation local & Roofing CEFD/UFSM \\
\hline Available area & $\begin{array}{l}\text { Roofing with two face (North and South) with } 2^{\circ} \text { of } \\
\text { inclination }\end{array}$ \\
\hline Dimension of face of the roofing & $10.72 \mathrm{~m}$ (width) e $39 \mathrm{~m}$ (lenght) \\
\hline Area of face of the roofing & $418.08 \mathrm{~m}^{2}$ \\
\hline Total area roofing & $836.16 \mathrm{~m}^{2}$ \\
\hline \multicolumn{2}{|l|}{ Flat plate solar collector } \\
\hline Real area collect & $0.9375 \mathrm{~m}^{2} /$ unit \\
\hline Effective area collect & $0.9375 \mathrm{~m}^{2} /$ unit \\
\hline Possible amount of install & 480 units \\
\hline Total area collect & $450 \mathrm{~m}^{2}$ \\
\hline Collector inclination & $45^{\circ}$ to the horizontal \\
\hline Additional load with collector full & $13 \mathrm{~kg} \mathrm{~m}^{-2}$ \\
\hline \multicolumn{2}{|l|}{ Evacuated tube solar collector } \\
\hline Real area collect & $2.8116 \mathrm{~m}^{2} /$ unit \\
\hline Effective area collect & $1.9800 \mathrm{~m}^{2} /$ unit \\
\hline Possible amount of install & 180 units \\
\hline Total area collect & $356.4 \mathrm{~m}^{2}$ \\
\hline Collector inclination & $45^{\circ}$ to the horizontal \\
\hline Additional load with collector full & $35 \mathrm{~kg} \mathrm{~m}^{-2}$ \\
\hline
\end{tabular}

For environmental analysis, Life Cycle Assessment was performed with software SimaPro ${ }^{\circledR}$ 7.3.2, which has been widely used for LCA of solar collectors (Battisti and Corrado, 2005; Rey-Martínez et al., 2008; Simons and Firth, 2011; Hang et al., 2012). This particular study used the Ecoinvent 2.2 database, which is already included in the software and chosen the Eco-Indicator 99 as method of impact evaluation. The stages of the life cycle were based on the ISO 14040 (2006) standard, which regulates and presents the necessary steps for LCA application. The phases of LCA are divided into four main parts: goal and scope, inventory analysis, impact assessment and interpretation of the results.

The LCA performed in this study focused only on the production of flat plate and evacuated tube solar collectors based on the fact that $89-99 \%$ of total energy consumption is associated with the production 
and acquisition of raw materials used to manufacture them (Ardente et al., 2005; Masruroh et al., 2006). All data of production of the collectors was obtained directly from database of the software.

The number of units of each type of collector was calculated based on the total area available for the installation, so it was adopted as functional unit the total area under of the CEFD roofing. However, in the SimaPro ${ }^{\circledR}$, was allocated the amount, in square meters, concerning the amount to be installed of each type of collector.

The Fig. 3 represents a schematic of the system boundary assumed to comparison of the production process of the types of solar collectors.

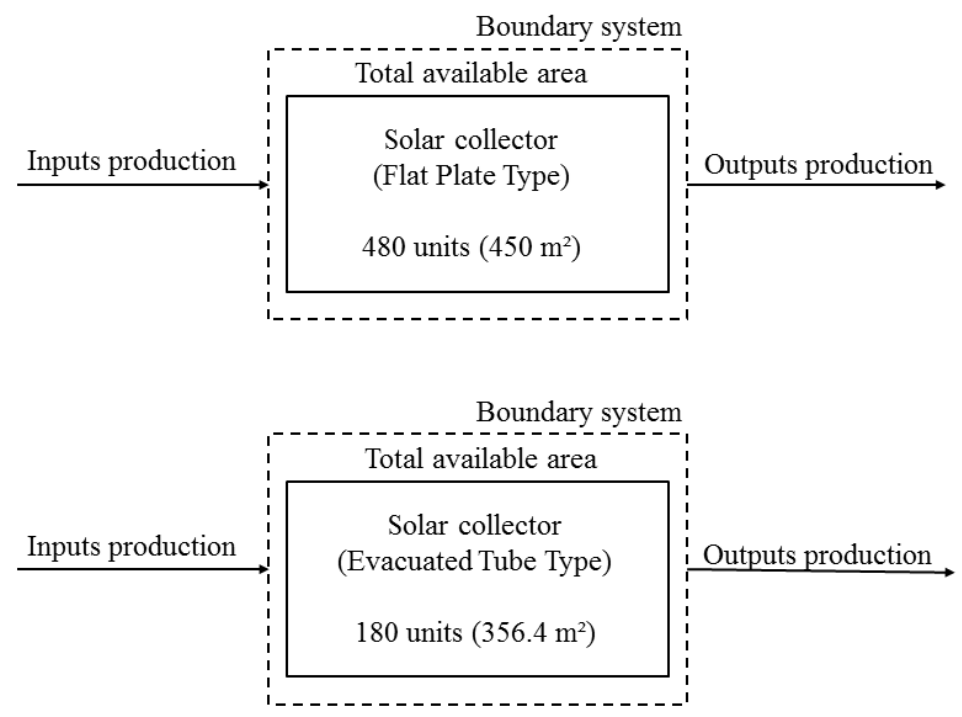

Figure 3. Boundaries system

The input and output flows related to the production of each type of collector is presented in Table 2 (flat plate collectors) and Table 3 (evacuated tube collectors), and were obtained directly from database software.

For the economic analysis, was evaluated the cost of the collectors and also the accessories (such as pumps, connections and others) to the final system installation. It is noteworthy that the environmental analysis was only considered the manufacturing process of flat plate solar collector type and the type evacuated tube. Was evaluated the entire deployment system because the amount of equipment and their specifications may vary for each type of collector, as shown in the diagram in Fig. 4, resulting in an overall cost different for both.

The economic analysis was based on the initial costs of installation and the operating costs of the solar heating system, with the data being collected through an economic feasibility study conducted at the above-mentioned Physical Education and Sports Centre at UFSM. However, environmental analysis focused only on the potential environmental impact of the manufacture of solar collectors, since the analysis did not evaluate the installation steps and operation by the fact that a proposed project and that it needed approval or disapproval. The estimation of initial costs did not take into account either the fixture-plate system or freight and manpower costs, but an extra percentage of $10 \%$ was added for any other costs and extra expenses. Operating costs are based on electricity consumption by the pumping system of collectors and maintenance expenses, which consists of cleaning the tubes to remove dust and dirt that can impair the absorption of solar radiation. 
Table 2. Properties of the manufacturing process of flat plate collectors

\begin{tabular}{lll}
\hline Materials/fuels & Amount & Unity \\
\hline Electricity, medium voltage, at grid/CH U & 1.16 & $\mathrm{kWh}$ \\
\hline Tap water, at user/RER U & 9.4 & $\mathrm{~kg}$ \\
\hline Water, completely softened, at plant/RER U & 1.38 & $\mathrm{~kg}$ \\
\hline Solar collector factory/RER/I U & $2 \mathrm{E}-07$ & $\mathrm{p}$ \\
\hline Rock wool, packed, at plant/CH U & 2.43 & $\mathrm{~kg}$ \\
\hline Corrugated board, mixed fibre, single wall, at plant/CH U & 3.68 & $\mathrm{~kg}$ \\
\hline Solar glass, low-iron, at regional storage/RER U & 9.12 & $\mathrm{~kg}$ \\
\hline Synthetic rubber, at plant/RER U & 0.732 & $\mathrm{~kg}$ \\
\hline Silicone product, at plant/RER U & 0.0588 & $\mathrm{~kg}$ \\
\hline Propylene glycol, liquid, at plant/RER U & 1.01 & $\mathrm{~kg}$ \\
\hline Aluminium, production mix, wrought alloy, at plant/RER U & 3.93 & $\mathrm{~kg}$ \\
\hline Brazing solder, cadmium free, at plant/RER U & 0.00368 & $\mathrm{~kg}$ \\
\hline Soft solder, Sn97Cu3, at plant/RER U & 0.0588 & $\mathrm{~kg}$ \\
\hline Copper, at regional storage/RER U & 2.82 & $\mathrm{~kg}$ \\
\hline Chromium steel 18/8, at plant/RER U & 4.14 & $\mathrm{~kg}$ \\
\hline Transport, transoceanic freight ship/OCE U & 95.5 & $\mathrm{tkm}$ \\
\hline Transport, lorry 20-28t, fleet average/CH U & 1.4 & $\mathrm{tkm}$ \\
\hline Transport, lorry >16t, fleet average/RER U & 11.7 & $\mathrm{tkm}$ \\
\hline Transport, freight, rail/RER U & 16.8 & $\mathrm{tkm}$ \\
\hline Selective coating, copper sheet, black chrome/RER U & 1 & $\mathrm{~m} 2$ \\
\hline Anti-reflex-coating, etching, solar glass/DK U & 1 & $\mathrm{~m} 2$ \\
\hline Sheet rolling, copper/RER U & 2.82 & $\mathrm{~kg}$ \\
\hline Heat, waste & 4.16 & $\mathrm{MJ}$ \\
\hline Disposal, building, glass sheet, to sorting plant/CH U & 9.12 & $\mathrm{~kg}$ \\
\hline Disposal, building, mineral wool, to sorting plant/CH U & 2.43 & $\mathrm{~kg}$ \\
\hline Disposal, plastics, mixture, 15.3\% water, to municipal incineration/CH U & 0.79 & $\mathrm{~kg}$ \\
\hline Disposal, packaging cardboard, 19.6\% water, to municipal incineration/CH U & 3.68 & $\mathrm{~kg}$ \\
\hline Treatment, sewage, from residence, to wastewater treatment, class 2/CH U & 0.0094 & $\mathrm{m3}$ \\
\hline Treatment, heat carrier liquid, 40\% C3H8O2, to wastewater treatment, class 2/CH U & 0.00239 & $\mathrm{m3}$ \\
\hline & & \\
\hline
\end{tabular}



Figure 4. Generic system for swimming pools 
Table 3. Properties of the manufacturing process of evacuated tube collectors

\begin{tabular}{|c|c|c|}
\hline Materials/process & Amount & Unity \\
\hline Electricity, medium voltage, at grid/GB U & 17 & $\mathrm{kWh}$ \\
\hline Natural gas, burned in industrial furnace low-NOx $>100 \mathrm{~kW} / \mathrm{RER} U$ & 16.5 & MJ \\
\hline Tap water, at user/RER U & 53.6 & $\mathrm{~kg}$ \\
\hline Water, completely softened, at plant/RER U & 0.9 & $\mathrm{~kg}$ \\
\hline Solar collector factory/RER/I U & 0.0000002 & $\mathrm{p}$ \\
\hline Chemicals organic, at plant/GLO U & 0.0113 & $\mathrm{~kg}$ \\
\hline Hydrochloric acid, $30 \%$ in $\mathrm{H} 2 \mathrm{O}$, at plant/RER $\mathrm{U}$ & 0.113 & $\mathrm{~kg}$ \\
\hline Corrugated board, mixed fibre, single wall, at plant/RER $U$ & 3.33 & $\mathrm{~kg}$ \\
\hline Glass tube, borosilicate, at plant/DE U & 14.2 & $\mathrm{~kg}$ \\
\hline Synthetic rubber, at plant/RER $U$ & 0.667 & $\mathrm{~kg}$ \\
\hline Rock wool, packed, at plant/CH U & 2.03 & $\mathrm{~kg}$ \\
\hline Silicone product, at plant/RER U & 0.0533 & $\mathrm{~kg}$ \\
\hline Copper, at regional storage/RER $U$ & 2.8 & $\mathrm{~kg}$ \\
\hline Brazing solder, cadmium free, at plant/RER U & 0.1 & $\mathrm{~kg}$ \\
\hline Propylene glycol, liquid, at plant/RER U & 0.654 & $\mathrm{~kg}$ \\
\hline Chromium steel $18 / 8$, at plant/RER $U$ & 4 & $\mathrm{~kg}$ \\
\hline Transport, lorry $>16 t$, fleet average/RER $U$ & 16.8 & $\mathrm{tkm}$ \\
\hline Transport, freight, rail/RER U & 16.8 & $\mathrm{tkm}$ \\
\hline Selective coating, copper sheet, physical vapour deposition/DE U & 1 & $\mathrm{~m} 2$ \\
\hline Anti-reflex-coating, etching, solar glass/DK U & 1 & $\mathrm{~m} 2$ \\
\hline Sheet rolling, copper/RER U & 2.8 & $\mathrm{~kg}$ \\
\hline Heat, waste & 61.3 & MJ \\
\hline Disposal, building, glass sheet, to sorting plant/CH U & 14.2 & $\mathrm{~kg}$ \\
\hline Disposal, plastics, mixture, $15.3 \%$ water, to municipal incineration/CH U & 0.72 & $\mathrm{~kg}$ \\
\hline Disposal, packaging cardboard, $19.6 \%$ water, to municipal incineration/CH U & 3.33 & $\mathrm{~kg}$ \\
\hline Disposal, building, mineral wool, to sorting plant/CH U & 2.03 & $\mathrm{~kg}$ \\
\hline $\begin{array}{l}\text { Treatment, heat carrier liquid, } 40 \% \mathrm{C} 3 \mathrm{H} 8 \mathrm{O} 2 \text {, to wastewater treatment, class } \\
2 / \mathrm{CHU}\end{array}$ & 0.00155 & m3 \\
\hline Disposal, municipal solid waste, $22.9 \%$ water, to municipal incineration/CH U & 0.0284 & $\mathrm{~kg}$ \\
\hline Disposal, glass, $0 \%$ water, to inert material landfill/CH U & 0.68 & $\mathrm{~kg}$ \\
\hline Disposal, hazardous waste, $25 \%$ water, to hazardous waste incineration/CH U & 0.227 & $\mathrm{~kg}$ \\
\hline Treatment, sewage, from residence, to wastewater treatment, class $2 / \mathrm{CH} U$ & 0.0442 & m3 \\
\hline
\end{tabular}

\section{Results and Discussion}

\subsection{Economic Analysis}

Tables 4 and 5 as well as Tables 6 and 7 shows the purchase and operation costs of the flat plate collectors and the evacuated tube collectors for the same performance, respectively. The discussions for the economic analysis will be centred on the acquisition costs, since the operational costs are the same. The analysis of Tables 4 and 6 shows that the initial investment required to install the solar system with evacuated tube collectors is $104.04 \%$ higher. Both the systems possesses the item "Plates with 
connections and mounting" as the major cost, corresponding about $90 \%$ of the total value for the evacuated tube collector and $86 \%$ for the flat plate collector.

Table 4. Purchase costs: flat plate collector

\begin{tabular}{llll}
\hline Item & Units & Unit value (US\$)* & Total (US\$)* \\
\hline Plates with connections and mounting & 480 & 106.93 & 48118.50 \\
\hline Controller with thermostats & 1 & 407.78 & 407.78 \\
\hline Circulation pump & 2 & 203.89 & 407.78 \\
\hline Valves & 10 & 17.47 & 174.75 \\
\hline Pipes - 6m (2") & 17.5 & 17.47 & 301.87 \\
\hline Pipe insulation & 105 & 1.45 & 152.78 \\
\hline Connections & 60 & 0.73 & 54.75 \\
\hline Insulation boards: expanded polystyrene & 450 & 2.91 & 1311.75 \\
\hline Extras: Percentage of total costs & $10 \%$ & 5093.00 & 5093.00 \\
\hline Total & & & 56022.96
\end{tabular}

* Values corrected for the current year by INPC (National Consumer Price Index) and converted to Brazilian reais to US dollar (1 BRL $=0.5$ US dollar).

Table 5. Operating costs: flat plate collector

\begin{tabular}{llll}
\hline Item & Units & Unit cost (US\$)* & Total (US\$)* \\
\hline Cleaning of plates & 12 & 34.95 & 419.46 \\
\hline Operational: electric energy & 1 & 702.92 & 702.92 \\
\hline Total: US\$/year & & & 1122.38 \\
\hline
\end{tabular}

* Values corrected for the current year by INPC (National Consumer Price Index) and converted to Brazilian reais to US dollar ( $1 \mathrm{BRL}=0.5$ US dollar).

Table 6. Purchase costs: evacuated tube collector

\begin{tabular}{llll}
\hline Item & Units & Unit cost (US\$)* & Total (US\$)* \\
\hline Plates with connections and mounting & 180 & 286.89 & 102419.70 \\
\hline Controller with thermostats & 1 & 407.78 & 407.78 \\
\hline Circulation pump & 2 & 203.89 & 407.78 \\
\hline Valves & 10 & 17.48 & 174.75 \\
\hline Pipes - 6m (2") & 17,5 & 17.47 & 301.87 \\
\hline Pipe insulation & 105 & 1.46 & 152.77 \\
\hline Connections & 60 & 0.73 & 54.75 \\
\hline Extras : Percentage of total costs & $10 \%$ & 10391.94 & 10391.94 \\
\hline Total & & & 114311.40 \\
\hline
\end{tabular}

* Values corrected for the current year by INPC (National Consumer Price Index) and converted to Brazilian reais to US dollar (1 BRL $=0.5$ US dollar).

Table 7. Operating costs: evacuated tube collector

\begin{tabular}{llll}
\hline Item & Units & Unit cost (US\$)* & Total (US\$)* \\
\hline Cleaning of the plates & 12 & 34.95 & 419.46 \\
\hline Operational: electric energy & 1 & 702.92 & 702.92 \\
\hline Total: US\$/year & & & 1122.38 \\
\hline
\end{tabular}

* Values corrected for the current year by INPC (National Consumer Price Index) and converted to Brazilian reais to US dollar (1 BRL $=0.5$ US dollar). 


\subsection{Environmental analysis}

Fig. 5 shows the result produced by SimaPro ${ }^{\circledR}$ according to the chosen impact evaluation method (EcoIndicator 99). The analysis of the results illustrated in Fig. 5 shows that the flat plate collector causes the most damage and is responsible for major impacts in 10 out of the 11 impact categories investigated. Flat plate collectors inflict less environmental damage in only one category of impact: land use. This is because, in order to obtain the same performance, 480 units (or $450 \mathrm{~m}^{2}$ ) of flat plate collectors are necessary (according to Table 1) compared to 180 units (or $356.4 \mathrm{~m}^{2}$ ) of evacuated tube collectors. Therefore, a greater amount of space is required to install flat plates.

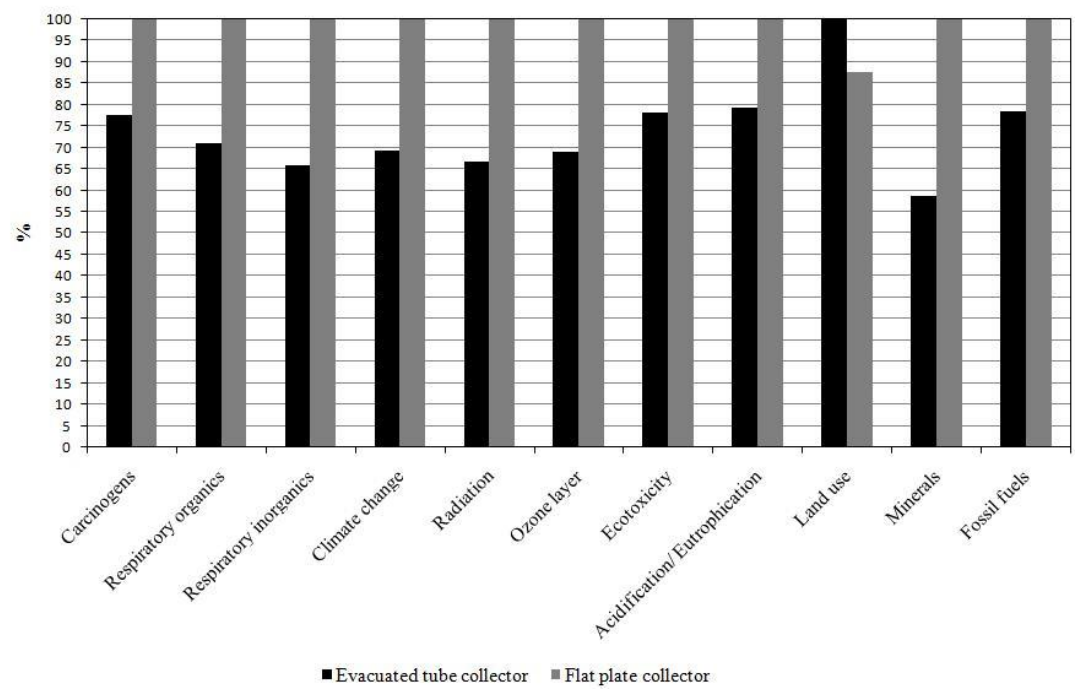

Figure 5. Comparison of the life cycle of the output of collector plates by characterization

Following the comparison of the manufacturing process of both types of solar collectors, Fig. 6 shows the category that causes the greatest impact on the individual production of each type of collector in the long term, so that the different pollution sources can be quantified.

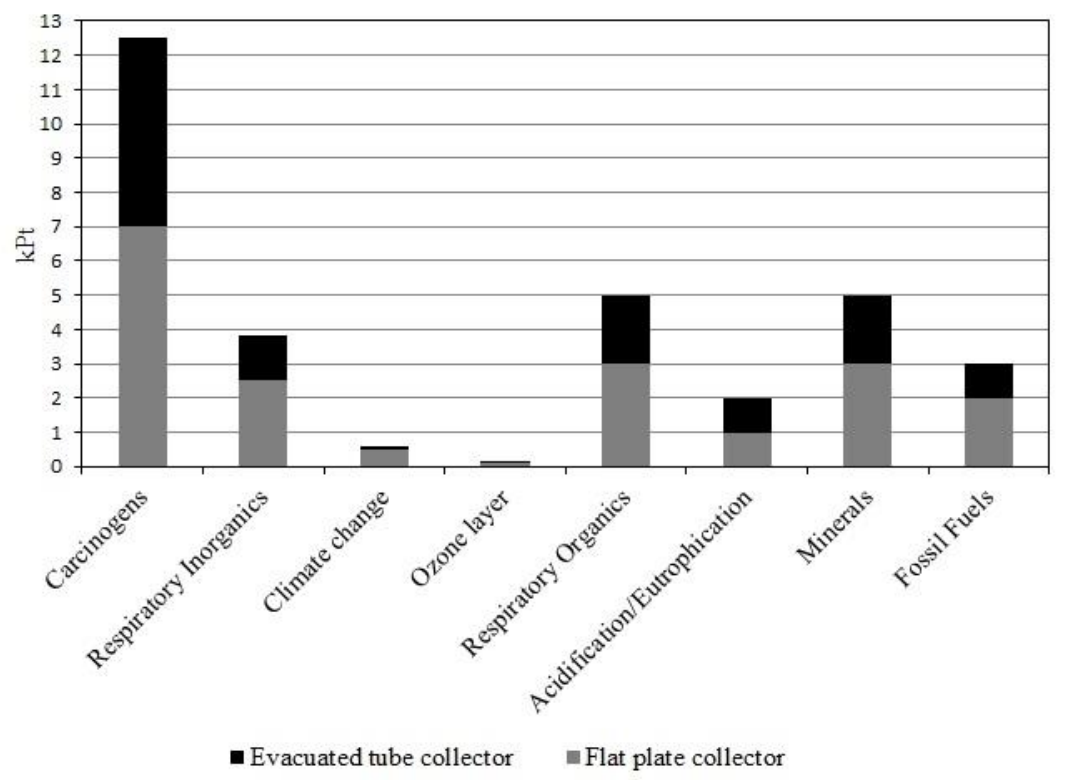

Figure 6. Comparison of the life cycle of the output of solar collectors by single score

It can be seen that the main category causing environmental impact in both collectors is that of carcinogens. This fact is possibly associated with the consumption and emission of arsenic and cadmium ions which are harmful to living beings (Kerdthep et al., 2009). From the total of this category, $55.61 \%$ 
corresponds to arsenic ions and $35.66 \%$ to cadmium ions, for flat plates, while for the evacuated tubes are $54.72 \%$ and $34.42 \%$, respectively, according the results obtained from SimaPro ${ }^{\circledR}$. The second-most polluting class is not the same in the two types of solar collectors; in flat plate collectors, minerals are the major sources of pollution because of a greater presence of nickel in manufacturing. For evacuated tube collectors, the greatest pollutant is the category respiratory inorganic, as a result of the emission of particulate materials.

\section{Conclusions}

The obtained results lead to the conclusion that, from the environmental point of view, evacuated tube solar collectors are the best choice, considering the least impact generated during their manufacture, among the analyzed categories. However, from the economic perspective, it is clear that a greater investment is needed to acquire the collector system of evacuated tubes. Considering the apparent ambiguity of the results obtained, it is perceived that the choice for the type of collector depends on the desired advantage; besides, a complement is required for decision-making. The example investigated in this study was the heating system of the water of the CEFD swimming pools that has fuel oil as heat source, which is intended to be partially replaced with a solar heating system. Thus, for a situation where there are not enough financial resources, the choice for flat plate collectors is more attractive, even though their production process is more polluting. There will certainly be less environmental impact anyway because of the absence of combustion gases in the operational phase compared to the original system. Otherwise, evacuated tubes are the most advisable option when funding is available. Moreover, it should be noted that LCA is very important as a tool that can provide a complete environmental view of a process, assisting the decision-making processes in conflicts between economic, social and environmental variables.

\section{References}

Ardente F, Beccali G, Cellura M and Brano V L (2005), Life cycle assessment of a solar thermal collector, Renewable Energy, 30, 1031-1054.

Battisti R and Corrado A (2005), Environmental assessment of solar thermal collectors with integrated water storage, Journal of Cleaner Production, 13, 1295-1300.

Cellura M, Longo S and Mistretta M (2011), Sensitivity analysis to quantify uncertainty in Life Cycle Assessment: The case study of an Italian tile, Renewable and Sustainable Energy Reviews, 15, 4697-4705.

Hang Y, Qu M and Zhao F (2012), Economic and environmental life cycle analysis of solar hot water systems in the United States, Energy and Buildings, 45, 181-188.

ISO 14040 (2006). Environmental management - Life cycle assessment, principles and framework, http://www.iso.org. Accessed 10 Jan 2014.

Kalogirou S.A. (2004), Solar thermal collectors and applications, Progress in Energy and Combustion Science, 30, 231-295.

Kalogirou S.A. (2009), Thermal performance, economic and environmental life cycle analysis of thermosiphon solar water heaters, Solar Energy, 83, 39-48.

Kerdthep P., Tongyonk L. and Rojanapantip L. (2009), Concentrations of cadmium and arsenic in seafood from muang district, Rayong province, International Journal of Health Research, 23, 179-184.

Kim J., Kwak H.Y. and Lee D.W. (2007), An analytical study on the thermal characteristics of flat-plate and evacuated solar collectors, Journal Mechanical Science and Technology, 21, 2159-2167.

Masruroh N.A., Li B. and Klemes J. (2006), Life cycle analysis of a solar thermal system with thermochemical storage process, Renewable Energy, 31, 537-548.

Matuska T. and Sourek B. (2006), Façade solar collectors, Solar Energy, 80, 1443-1452.

Michels A., Mayer F.D., Gallon R., Hoffmann R. and Serafini S.T. (2008), Fossil fuel saving through a direct solar energy water heating system, Clean Soil Air Water, 36, 743-747. 
Muthusivagami R.M., Velraj R. and Sethumadhavan R. (2010), Solar cookers with and without thermal storage - A review, Renewable and Sustainable Energy Reviews, 14, 691-701.

Ozsabuncuoglu I.H. (1995), Economic analysis of flat plate collectors of solar energy, Energy Policy, 23, 755-763.

Pehnt M. (2006), Dynamic life cycle assessment (LCA) of renewable energy technologies, Renew Energy, 31, 55-31.

Rey-Martínez F.J., Velasco-Gómez E., Martín-Gil J., Gracia L.M.N. and Navarro S.H. (2008), Life cycle analysis of a thermal solar installation at a rural house in Valladolid (Spain), Environmental Engineering Science, 25, 713-723.

Simons A. and Firth S.K. (2011), Life-cycle assessment of a $100 \%$ solar fraction thermal supply to a European apartment building using water-based sensible heat storage, Energy and Building, 43, 1231-1240.

Smyth M., Eames P.C. and Norton B. (2000), Life cycle assessment of a heat retaining integrated collector/storage solar water heater (ICSSWH), In: World Renewable Energy Congress VI (WREC2000), 1036-1040.

Szargut J. and Stanek W. (2007), Thermo-ecological optimization of a solar collector, Energy, 32, 584-590

Tsilingiridis G., Martinopoulos G. and Kyriakis N. (2004), Life cycle environmental impact of a thermosyphonic domestic solar hot water system in comparison with electrical and gas water heating, Renewable Energy, 29, 1277-1288.

Zambolin E and Col D.D. (2010), Experimental analysis of thermal performance of flat plate and evacuated tube solar collectors in stationary standard and daily conditions, Solar Energy, 84, 1382-1396. 